\title{
ANALYSIS OF COMPETITIVENESS OF RAILWAY PASSANGER TRANSPORT BETWEEN RAKOVNÍK AND PRAGUE
}

\author{
Rudolf VÁvra*, Vít Janoš \\ Department of Logistics and Management of Transport, Faculty of Transportation Sciences, CTU in Prague, \\ Czech Republic \\ * corresponding author: vavrarud@fd.cvut.cz
}

Abstract. This paper deals with the issue of railway connection between Rakovník and Prague. Initially, there is made an analysis of the transport supply and analysis of modal split. Additionally, an operation concept is suggested in order to increase the attractiveness of the railway passenger transport, afterward, the transport possibilities, which can be accomplished by this approach, are evaluated.

KEYWORDS: modal split, transport supply, logit model, operation concept, periodic timetable, travel time, public transport.

\section{INTRODUCTION}

The article deals with examining the competitiveness of the railway connection between Prague and Rakovník. Rakovník (16081 inhabitants) is a town located in the western part of Středočeský kraj (region of middle Bohemia), outside the suburban area of Prague, but some properties are similar to a suburban area - has strong daily transport relations due Prague (according to the census from 2011 about 738 people daily). Rakovník to Prague does have good bus connection, but due to the existence of the railway connection in this session, and the advantages of rail transport through the continuous passage of agglomeration areas should address the issue of the attractiveness of this mode of transport.

Among solved railway lines are included (line numbers by railway timetable SŽDC):

- 120 Praha - Kladno - Rakovník,

- 171 Praha - Beroun,

- 173 Praha - Rudná u Prahy - Beroun,

- 174 Beroun - Rakovník.

The aim is to examine the competitiveness of rail passenger transport in relation Rakovník - Prague, using the current infrastructure, which includes:

- an analysis of the modal split for the current state,

- determination of the theoretical travel times possibilities of the train and comparing them with the travel times according to the current state,

- proposal schematic operational concept in term of technological possibilities,

- comparing travel times of created operational concept with travel times according to the current state and theoretically achievable travel times,

- determination of the modal split for the proposed operational concept and measurement of the difference in the modal split of proposed operational concept from the current situation.

\section{Methods}

To determine the share of individual vehicles on the modal split is used logit model, namely a two-step nested logit model:

$$
P_{i}=\frac{e^{\mu V_{i}}}{\sum_{j \in D P} e^{\mu V_{j}}}
$$

where $P_{i}$ means the probability of choice of transport mode $i, e$ is Euler's number, $D P$ is the set of all considered transport modes, $\mu$ means the elasticity of choice of transport mode on the basis of changes in generalized costs and $V_{i}$ means generalized costs expended for the journey by transport mean $i$. [1]

Nested logit model is phasing out the calculation in two phases. The first phase determines modal split between individual transport and public transport. The second phase examines then modal split of individual transport modes within public traffic.

\subsection{FirST PHASE}

In the first phase it is necessary to determine the generalized cost of individual car transport and public transport. Within public transport there is selected that transport mode of public transport, that is more favourable for the journey.

Generalized costs of individual car transport $\left(V_{I A D}\right)$ are calculated using the Formula 1, where $D_{k m}$ is length of the journey (in $\mathrm{km}$ ), $N_{I A D}$ are costs for 1 $\mathrm{km}$ of the journey, $O_{I A D}$ is the average occupancy of the vehicle, $D_{I A D}$ čas is travel time (in hours), $W_{\text {čas }}$ is the perceived value of time (in CZK/hour) and $D_{I A D}$ dost is an indicator of time availability in hours (includes attendance from origin of the journey to the car, time attendance from the car to final destination, time for finding a parking space, etc.).

Generalized costs of public transport $\left(V_{V D}\right)$ are calculated using the Formula 2, where $D_{V D}$ čas is travel 


$$
\begin{gathered}
V_{I A D}=D_{k m} * \frac{N_{I A D}}{O_{I A D}}+D_{I A D \check{c} a s} * W_{\check{c} a s}+D_{I A D \text { dost }} * W_{\check{c} a s} \\
V_{V D}=\left(D_{V D \check{c} a s} * W_{\check{c} a s}+D_{V D \text { dost }} * W_{\check{c} a s}+J_{V D}+I_{V D, 1 / 2} * W_{\check{c} a s}\right) * C_{V D-I A D}
\end{gathered}
$$

time (in hours), $W_{\text {čas }}$ is the perceived value of time (in CZK/hour), $D_{V D}$ dost is an indicator of time availability in hours (time attendance from origin of the journey to the stop/station of public transport, time attendance from the stop/station to final destination), $J_{V D}$ is fare (in CZK), $I_{V D, 1 / 2}$ is half the interval between links (in hours) and $C_{V D-I A D}$ is the calibration constant of mode choice. [1]

The result of the first phase and are therefore values $P_{I A D}$ and $P_{V D}$ indicating the probability of the use of individual car traffic and public transport in the appropriate relation.

\subsection{SECOND PHASE}

In second phase there is necessary to determine generalized costs $\left(V_{i}\right)$ for relevant modes $i$ of public transport. Determination of these costs is performed according to the Formula 3 where $D_{i}$ čas is travel time (in hours) using transport mode $i, W_{\check{c} \text { cas }}$ is the perceived value of time (in $\mathrm{CZK} /$ hour), $D_{i}$ dost is time availability of the transport mode $i$ (in hours), $J_{i}$ is fare using transport mode $i$ (in CZK) and $I_{i, 1 / 2}$ is half the interval between links of the transport mode $i$ (in hours). 1

Results of second phase are the conditional probabilities $P_{i \vee V D}$ of the use of transport mean $i$ under the condition of using public transport. The probability $P_{i}$ of use of the transport mean is thus given by $P_{i}=P_{V D} * P_{i \vee V D}$.

\section{Results And Discussion}

\subsection{AnAlysis OF SUPPLY CONNECTION DURING THE TIMETABLE 2015/2016}

Bus connection from Rakovník to Prague was during the timetable 2015/2016 accounted by lines 310610, 310612, 310613, which are operating between Rakovník bus station and stop Prague Hradčanská and further by lines 310270, 310700, 310710, which are operating between Rakovník bus station and stop Prague Zličín. Average aggregate interval between individual links reaches during peak hours 10 minutes. Shortest travel times between Rakovník and Hradčanská are about 55 to $75 \mathrm{~min}$. The shortest travel times between Rakovník and Zličín are about 40 to 55 min.

By train there is possible to go either using line 120 through Kladno or using the lines 174 and 171 (eventually 174 and 173) through Beroun.

On the line 120 are operated in 120 minutes period fast trains Praha - Rakovník. Connection Rakovník to Prague is complemented by a combination of fast regional trains Praha - Kladno (in 120 minutes period, between Praha - Kladno in leading with fast trains) and passenger trains Kladno - Rakovník (operated as the 120 minute period) with bond in the station Kladno. The connection is also completed in peak hours of working days with one pair of fast regional trains Rakovník - Prague. These connections are operated in periodic timetable.

On the line 174 are operated passenger trains Beroun - Rakovník, but without a fixed interval between links (i.e. not according periodic timetable). Their average interval during peak hours of working days is around 60 minutes. In Beroun is then formed a bond in direction Prague.

\subsection{AnAlysis of MODAL SPlit in timetable $2015 / 2016$}

For the analysis of the modal split between Prague and Rakovník were selected 3 relations. In Rakovník is always considered the town centre. In Prague, with respect to potential target for daily commuting, were selected these points: Vítězné náměstí, Anděl, Václavské náměstí. To analyze the modal split was used nested logit model described in Chapter 2

To determine values $D_{k m}$ and $D_{I A D}$ čas was used free route planner on website mapy.cz. The value $N_{I A D}$ is determined as the sum of the fuel cost per 1 $\mathrm{km}$ away (at an average consumption of 7 litres per 100 $\mathrm{km}$ ) and other costs per $1 \mathrm{~km}$ of ride (related to the operation and acquisition of the vehicle). Rates are taken from the Decree no. 328/2014 Coll., so $N_{I A D}=$ $6,213 \mathrm{CZK} / \mathrm{km}$. For the average occupancy of the vehicle according to Chmelík [1] was calculated with the value $O_{I A D}=2$. For variable value $D_{I A D}$ dost is selected $D_{I A D \text { dost }}=0,25 \mathrm{~h}$ ( 5 minutes attendance from the journey origin to the vehicle, 5 minutes attendance from the car to the final destination and 5 minutes time on finding a parking space and parking).

In the case of public transport is taken into account connection by bus and by train in the working day (on September Wednesday as an average traffic day) in the direction from Prague to Rakovník, with the departure of the train / bus from Prague in the time between 14:00 and 18:00. Values $D_{i}$ čas and $I_{i, 1 / 2}$ are based on supply of connections, with $I_{i, 1 / 2}=\frac{2}{p s}$, where $p s$ means the number of considered connections in the solved time period. The value of the availability $D_{i \text { dost }}$ of transport mean $i$ is determined by the route planner and includes: 


$$
V_{i}=D_{i \text { čas }} * W_{\check{c} a s}+D_{i d o s t} * W_{\check{c} a s}+J_{i}+I_{i, 1 / 2} * W_{\check{c} a s}
$$

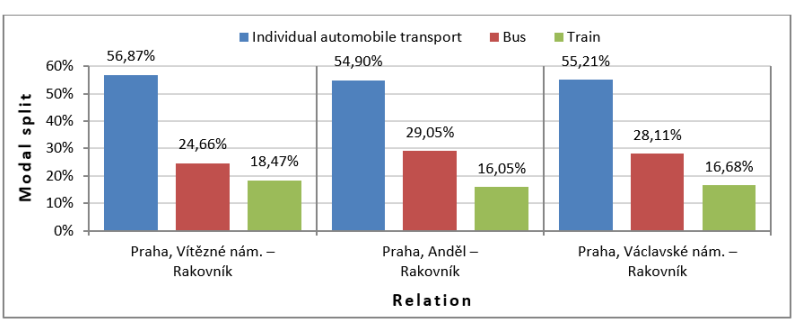

Figure 1. Current Modal Split.

- attendance of the reference point in Prague to the appropriate stop/station of transport mean $i$, or to the stop of Prague urban transport,

- attendance from the bus station in Rakovník, or from the railway station Rakovník to the town centre,

- additional reserve of $5 \mathrm{~min}$.

Fare $J_{i}$ is determined from the carriers' tariffs. For bus services is being considered at ordinary fare payment smart card, for rail services with custom fare IN 25, at the Prague urban transport then using annual coupon for an adult.

Perceived time value is calculated according to Chmelík [1] as 0.24 multiple of the average gross hourly wages, while gross monthly wage CZK 26480 and 168 working days in 2016 and 8 working hours per working day brings $W_{\text {čas }}=37,82857 \mathrm{CZK} /$ hour.

Values $\mu$ and $C_{V D-I A D}$ were chosen after Chmelík [1], therefore $C_{V D-I A D}=2,2, \mu=-0,0031$ for the first phase of the model and $\mu=-0,0123$ for second phase of the model.

The resulting values for modal split for the current state shows Figure 1 .

\subsection{Determination OF THE THEORETICALLY ACHIEVABLE TRAVEL TIMES}

Theoretically achievable travel time was determined on the basis of completely free infrastructure capacity. There are considered no stops and therefore is neglected a number of restrictive conditions.

To determine theoretically achievable rail travel time was used software FBS. Theoretically achievable travel times were determined for followed relations:

- Praha Masarykovo n. - Rakovník,

- Praha-Dejvice - Rakovník,

- Praha hl.n. - Rakovník,

- Praha-Smíchov - Rakovník.

Theoretically achievable travel times in these relations, as well as its comparison with the shortest travel time by train timetable $2015 / 2016$, the shortest travel time by bus (or in combination with Prague urban transport) and travel time by car, shows the graph in Figure 3

\subsection{The PROPOSAL OF SCHEMATIC OPERATIONAL CONCEPT BY THE REAL TECHNOLOGICAL POSSIBILITIES}

Despite the temporal lack of competitiveness of rail passenger services between Prague - Rakovník, which is evident from the graph in Figure 3. was for solved lines created schematic operational concept by the real technological possibilities, that would have the effect of increasing the value of modal split compared to current situation. This can be achieved in the following ways:

- shorting the travel times,

- shorting the interval between links,

- increasing number of direct rail links between Rakovník and Prague,

- using principles of integrated periodic timetable (IPT).

For creating the operational concept was used FBS.

On the line 120 there is proposed hourly operation of fast trains between Rakovník - Prague, instead of the current two-hour interval. The line reaches the broader IPT node in minute 00 in Rakovník. Regional trains Kladno - Rakovník are kept in a two-hour interval with bond to passenger trains Prague - Kladno in Kladno.

On lines 171 and 174 is proposed introducing of fast regional trains Prague - Beroun - Rakovník, which would be operated in 120 minutes interval. On the line 174 is also proposed to introduce two lines of trains, both kept in interval 120 minutes. IPT node in Minute 00 in Rakovník achieves, however, only one of them.

On the 173 was taken into account the introduction of peak 20 minutes interval between Prague Smíchov and Nučice station. For connection between Rakovník - Prague this line does not have much significance.

The proposed operational concept (for peak hours) is displayed in the form of interval graphics in the Figure 2

The graph in Figure 4 shows similar information as the graph in Figure 3 to which are added the shortest rail travel times from proposed operational concept.

\subsection{Determination OF THE MOdAL SPLit FOR THE PROPOSED OPERATIONAL CONCEPT}

For new proposed operational concept was calculated modal split again. It was used the same method of calculation as in Section 3.2 


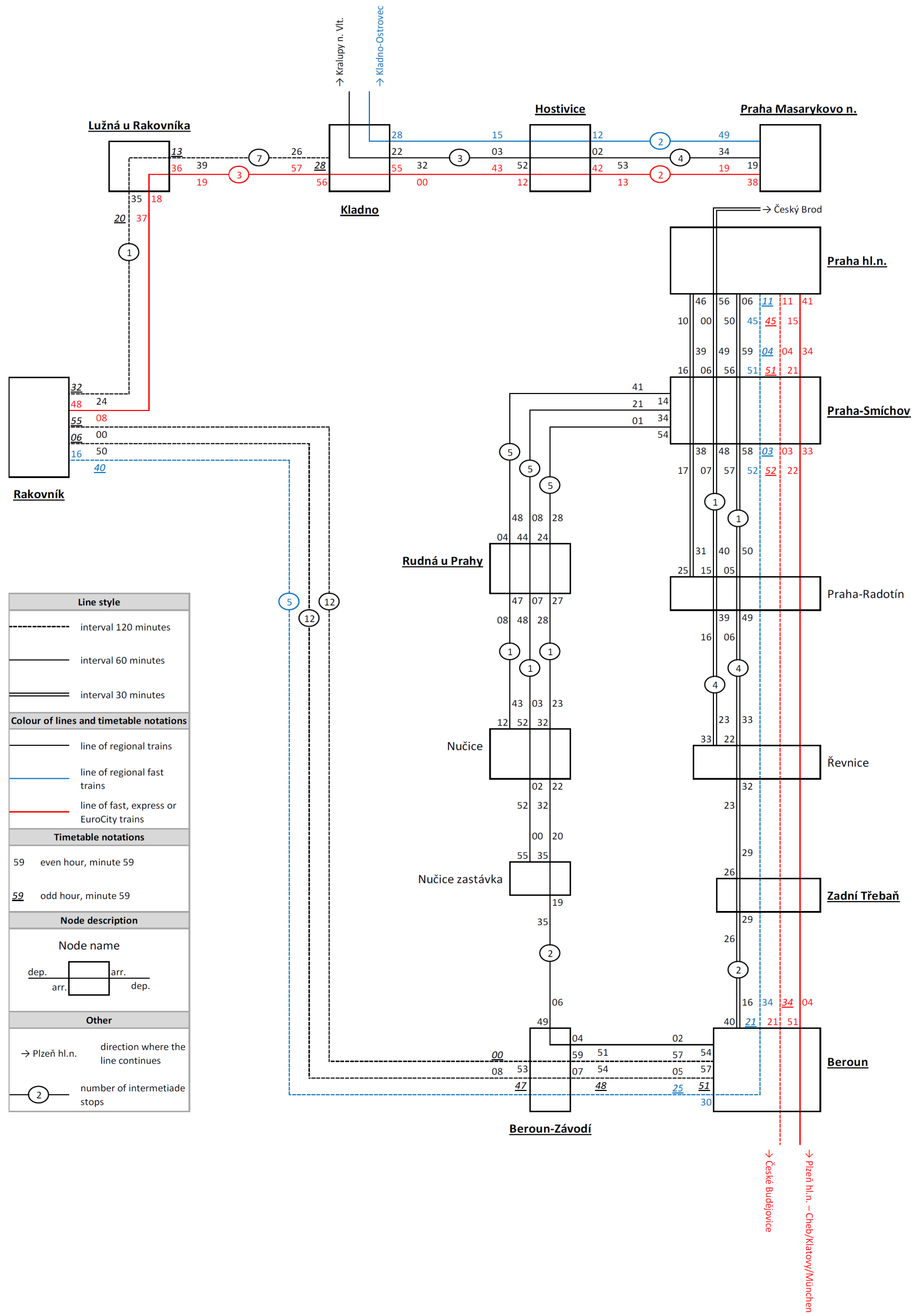

FigURE 2. Interval graphic of the proposed operational concept. 


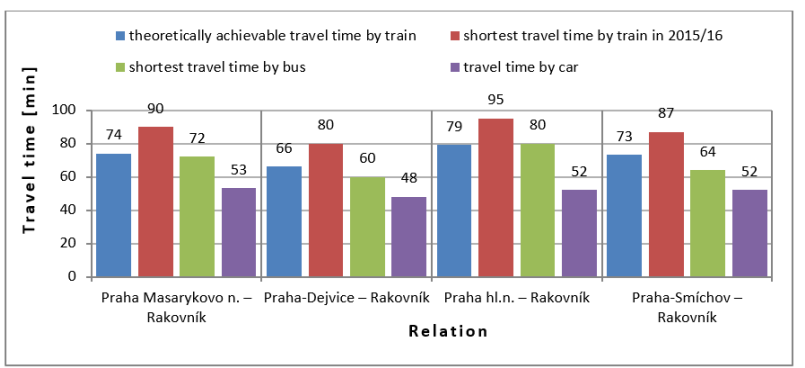

FiguRE 3. Comparison of theoretically achievable rail travel time.

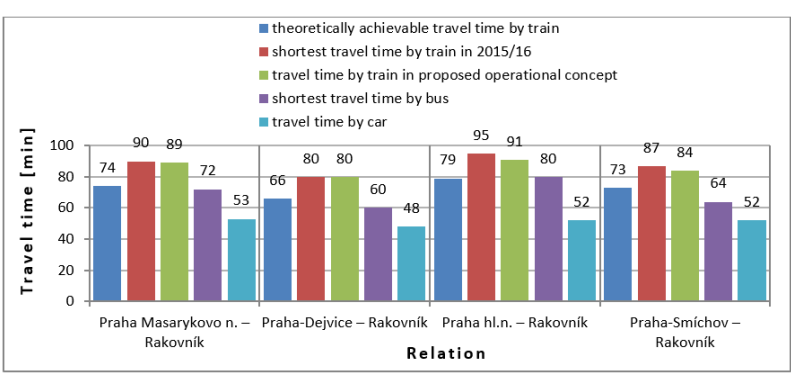

FiguRE 4. Comparison of theoretically achievable rail travel time, including shortest rail travel times from proposed operational concept.

Modal split for the proposed operational concept is shown in the graph in Figure 5. The graph in Figure 6 shows the modal shift of the proposed scheme compared to the level in force during the timetable $2015 / 2016$.

\section{Conclusions}

The aim was to examine the competitiveness of rail passenger transport between Rakovník and Prague. Of the share of modal split of the relevant transport modes in relation Rakovník - Prague, it was found, that the share of train is today in comparison with individual car traffic and the bus very low. Then there were determined for the train relation Rakovník - Prague theoretical possibilities of achievable travel time, and it was found, that even when neglecting a number of restrictive conditions, the train could not be between Prague and Rakovník time-competitive, even compared to the bus, let alone compared to individual car transport. To calculate the modal-split was used nested-logit model.

Then was created an operational concept aimed at increasing the attractiveness of passenger rail transport in relation Rakovník - Prague. For the proposed operational concept has been found, how the train travel time could be closer to the theoretically achievable travel time. For timetable construction was used FBS. It was found, which transportation options may be achieve due to new operational concept and for this solution were determined new values of the modal split. After comparing new values with the previous (original) the results shows, that despite the proposed offer in passenger rail service between Prague and

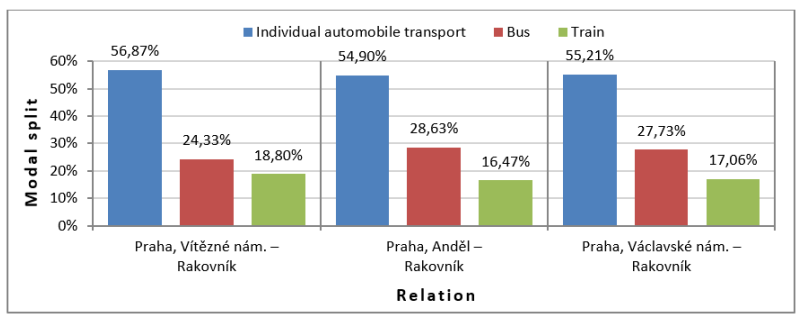

Figure 5. Modal split in relations Prague - Rakovník using the proposed operational concept.

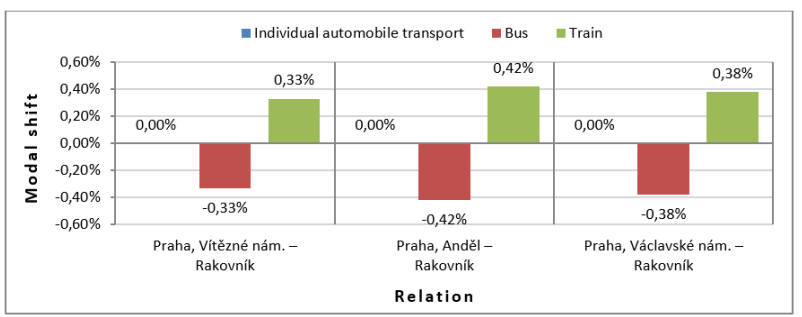

Figure 6. Modal shift in relations Prague - Rakovník using the proposed operational concept.

Rakovník was not achieved appreciable improvement, and value of modal split for the train increased by only $0.42 \%$.

The result of examination is that possibilities of contemporary rail infrastructure are so limited, that changes in timetable concept and offer of more connection does not allow significant improvements. So it is confirmed, that between Rakovník and Prague is not possible to achieve fundamental changes in the modal split without significant changes on to the rail infrastructure.

\section{REFERENCES}

[1] J. Chmelík. Assessments of Modal Split in Long-distance Passenger Transport [PDF]. Review of Economic Perspectives - Národohospodářský obzor, 2015. [cit. 2016-08-01]. 